\begin{tabular}{ll}
\hline \hline MINING AND METALLURGY INSTITUTE BOR & ISSN: 2334-8836 (Štampano izdanje) \\
UDK: 622 & ISSN: 2406-1395 (Online) \\
\hline \hline
\end{tabular}

Gordana Milentijevic', Blagoje Nedeljkovic *

\title{
THEORETICAL ASSUMPTIONS IN DEVELOPMENT THE UNDERGROUD FACILITIES IN DIFFERENT GEOMECHANICAL CONDITIONS**
}

\begin{abstract}
The aim of this paper is to achieve a rational rates in development the underground facilities at the lowest costs of construction and possible maximum quality (in this case, under the quality is implied the satisfactory stability of contour of developed room and excavation profile as close to the shape and size of designed).

The applied research methods include analyzing development the underground facilities as a complex system with a significant number of maximum-dependent elements that are within this complex system, conditioned by the work environment, organization, mechanization, energy and other factors for achievement of this objective.

The results of these studies indicate that the construction process of development the underground facilities is functionally linked and depends on a whole range of interrelated factors. As the result, it is obtained that the corresponding mathematical models can define an optimal technology and organization of work for construction the underground facilities.

Keywords: geomechanical conditions, production technology, underground rooms, systems, dependent elements, mathematical models
\end{abstract}

\section{INTRODUCTION}

Design of underground facilities, regardless of the type of facilities it concerns (corridors, excavations, inclines, manholes, chambers, tunnels and rooms for other purposes), is a very complex system with a significant number of interdependent elements, which are conditioned within this complex system: working conditions, organization, equipment, energy and other factors of importance in achievement the overall objective, achieving a rational rate of construction the rooms, at the lowest costs of construction and possible maximum quality ( in this case, under the quality is implies a satisfactory stability contours of developed room and excavation profile as close to the shape and size of designed).

By these very rigorous requirements, under the conditions of what is variable and often unknown rock mass, it is sometimes difficult to meet, for which there are many reasons: insufficient paying attention to the process of construction the underground facilities, insufficient knowledge on development conditions of facilities, inadequate technological manufacturing process, poor organization of work, equipment incompatibility with working conditions, lack of training of workers and many other factors. An objective assessment, if all the require-

\footnotetext{
*University of Pristina with temporary residency in Kosovska Mitrovica, Faculty of Technical Sciences, Kneza Miloša 7, Kosovska Mitrovica, e-mail: blagojenedeljkovic@yahoo.com

** Performed research was supported by the Ministry of Education, Science and Technological Development of the Republic of Serbia (Project No. III43007, Project No, TR33045)
} 
ments are met (the optimal rate of production, the lowest possible costs of manufacturing and quality of developed room), can be reached only after a detailed analysis, based on the large amount of information, which are reached by recording in the real working conditions of all elements in the technological system under the construction of facilities. Only, on the basis of an analysis of collected data, it is possible to assess the success of applied technology, equipment, organization and other elements that are a part of such system, to make closer the required amendments and supplements to the set requirements in respect of rationality and quality.

All complexity, related to the design of underground rooms is reflected through the independence of action and behavior of individual elements of the subsystems that are a part of technology development, as well as the large variability (in time and space) of working conditions and with these changes conditionality and changes of technological solutions, or individual ele-ments and parts of those subsystems. Also, the constant change of position of the work-place (head), working tools and workforce, are the reason for the changes of working conditions and efficiency of the process.

As the result of ongoing changes in the conditions of work, place of work and the efficiency of the operation, reduces the significance and reliability of the information gathered in one place to make decisions for work elsewhere, making it difficult, with frequent changes of working conditions, the definition of a unique technological solution of development and transport. The question of defining some unique technologies in these conditions is extremely complex. The production process becomes even more complex if the production of the observed object cannot be seen isolated from the system that surrounds it and with whom it is in the functional relationship. As an example, it can be noted that, the process of removing the mined material at the forefront of work site cannot be independent from the trans- port system and exports within the pit, the drilling process is not possible unless agreed with the possibility of supplying means for drilling with drive energy etc. All these examples show that the process of development the underground structure is functionally linked with the environment, and it depends on a whole series of interrelated factors, which can, for these purposes, be singled out as:

- working environment,

- organizational connections with the other technological processes in the system of pit,

- technological scheme of the pit,

- technological equipment of processes and

- importance of the underground facility for technological process of the pit as a whole.

All these factors directly affect the efficiency of technological process of the underground structure, and in particular must be studied. In view of complexity the construction process of underground faci-lities, and that the variability of factors influencing the process of design sometimes is significant, it is for assessments the design process or any of the elements of design, there is a need for a lot of information. Usually this information is obtained by direct recording of work processes and their elements and statistical analysis of the obtained data. Degree of their reliability is determined after that as well as finding, using mathematical methods, certain relationships and nature of their interdependence. Mathematically speaking, these relationships are usually stated in the form of dependency for required occurrence of one or more influential factors:

$$
F=f(a, b, c, \ldots) \text {. }
$$

Technology construction analysis of underground spaces can be done in several different ways, from which is a system of complex study the problems of construction and determining the significance of influential factors in the technological process now found the most supporters. This system 
allows the technological process of construction to be split into several subsystems (the working operations), and subsystems on constituent elements and procedures, which completely independently of each other, and as a whole, using a logical, mathematical and organizational modeling allows, in terms of different aspects to require an assessment of speed advancement - effectiveness, efficiency coefficient of available time, utilization of available capacity, equipment and workforce, norms, the prices of construction, quality of construction and others. System of complex study of production technologies, or elements and subsystems applied or designed technological process, can be very well used in organizing or analyzing almost applied technological process.

\section{METHODOLOGICAL APPROACH TO COMPLEX STUDY THE CONSTRUCTION TECHNOLOGY OF UNDERGROUND FACILITIES}

The system of studying the complex construction technology of underground facilities or some parts of technological process allows more objective consideration of all factors that are active in the framework of design either the work processes or cycles designed or applied technology development. Thanks to this perception factors and their interdependence, it is possible to make the appropriate innovations and changes on the existing technological processes, and on the newly designed ones, already in the very beginning, to harmonize organizational and technological relationships, all with the aim that the technological process reach flawlessly organizational and technological functions, in order to achieve maximum efficiency and with minimum investments.

In the analysis of such a system, first it is necessary to make a partition of influential factors according to their nature as:

- input,

- desired,

- organizational, and

- random - uncontrolled parameters.
Schematic presentation of such model is shown in Figure 1. (A) indicates parameters related to: mining - geological conditions, technological characteristics of the rock mass, equipment, etc. (B) indicates desired results: construction rate of facilities, performance, price of construction, etc. (C) indicates parameters of organizational - technical nature: operation regime, organization, mechanizational degree of working operations, the drilling and mining parameters (in case when the method of mining for different rock mass is used), material, etc. (D) indicates random or applied parameters of technological processes and stability characteristics of rock mass, unscheduled downtime related to: lack of energy, auxiliary materials, various jams and others. It should be borne in mind that desired result of (B), in addition to the basic influences of (A), largely depends on conditions and parameters given in (C), although the impact factors of (D) cannot be ignored, because sometimes these impacts can have a significant impact on formation the final decision and achievement the end effects. Knowing all these facts, it is necessary to accept the events that occur within one such model, a significant proportion have all three factors, so that the final result represents their common synthesis, which allows the mathematical expression of required values to be expressed in the form as:

$$
B=f \text { (A. C. D). }
$$

There is no doubt that such model can be dependent on a number of factors that, each individually, according to their impact on the ultimate outcomes can have different weights. Due to this this reason, and in order to rational and efficient solving the problem, it is necessary to highlight only those factors that have a significant impact on model behavior. Thus defined model allows that, according to the wishes and needs, find the best solutions (minimum or maximum values), but according to the character of occurrence and requested data. Figure 2 presents the scheme of model of technological systems in the field of construction related to the underground facilities. 


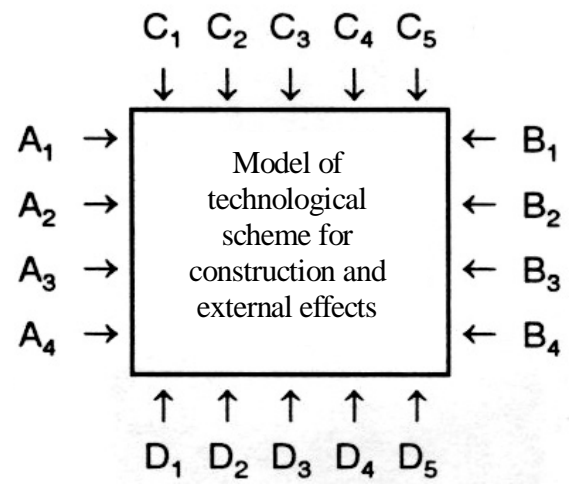

Figure 1 Schematic models of technological systems in the field of construction of underground facilities

Technological construction process of underground facilities (regardless of technological solutions), based on the dynamic plan development, represents a cyclic solution, in which in each cycle, constituent elements of the cycle are closely interlinked and carried out according to ahead established order, which enables this system to be observed as a stable system composed of several subsystems, which follow one another. Figure 2 shows a technological construction scheme, seen as a system composed of a number of independent subsystems.
Thus the formulated problem leads to the process of finding such alternative solutions, which, under the given conditions will provide the best results, not only of each subsystem, but the system as a whole. In solving these problems, it is necessary to perform an analysis from the following aspects: technological (real possibilities of application the analyzed solutions), organizational (possibility of organizing the implementation of analyzed solution) and time required to execute the scheduled job (selection of variants that are most favorable from the standpoint of time adaptation into the cycle and organizational scheme of the pit).

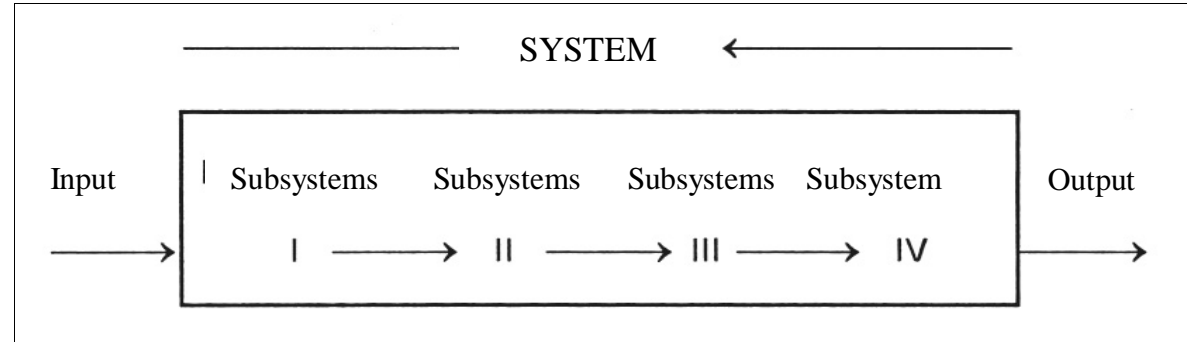

Figure 2 Schematic presentation of construction technology the underground facilities in a form of independent system composed of several subsystems which are closely linked:

I - Subsystem destruction of the rock mass; II - Ventilation subsystem of the worksite; III - Subsystem of loading and transportation the mined rock mass; IV - Subsystem of supporting facilities

Finding of criteria, based on which the optimal subsystems and systems will be determined, in terms of a large number of alternative solutions, represents a complex issue. Therefore, these studies show significantly more grateful finding the conditions 
of achieving the highest performance (in this case the highest advancement), with minimum of material costs (in this case the lowest price development). In mathematical theory, this procedure is known as the theory of reciprocity. This criterion is usually formed as the sum of individual criteria of occurrence (k), with a certain coefficient (f), which defines the signi-ficance of each of the observed occurrences:

$$
\mathrm{U}=\mathrm{f}_{1} \cdot \mathrm{k}_{1}+\mathrm{f}_{2} \cdot \mathrm{k}_{2}+\mathrm{f}_{\mathrm{n}} \cdot \mathrm{k}_{\mathrm{n}} \rightarrow \max (\min )
$$

In analyzing the technological procedure of underground structure, in case of different optional solutions, most often the problem was considered from the standpoint of achieving the highest rate of construction (v) at the lowest cost of construction (c). This criterion is given in the form of linear relationship, as follows:

$$
U=f \cdot\left(f_{1} \cdot c+f_{2} \cdot v\right) \text {, }
$$

where: $f_{1}<0$ i $_{2}>0-$ are the coefficients of weight, taking into account the importance of indicators of costs and rate of construction

In solving the practical cases and tasks, there is no aspire to obtain the ideal values of selected criteria, considering that the results, obtained by field observations, are not fully adequate to imaginary model.

\section{STRUCTURE OF SYSTEMS AND SUBSYSTEMS OF SELECTED CONSTRUCTION MODEL}

As the method of development the facilities, in this case, the system with destruction the rock mass on the room face by blasting was adopted. This kind of system consists of several subsystems, among which the following stand out as the main:

- subsystem destruction of rock mass (I),

- ventilation subsystem (II),

- loading and transportation subsystem of blasted rock materials (Ill), and

- supporting subsystem (IV).

Other subsystems: coming from and going to the worksites, preparation the work- sites, delivery of materials and auxiliary works (construction of water channels, extension of track, extension of tubes for compressed air, and pipes for water and separate ventilation), have been included in the organizational and regime works, and due to this reason will not be analyzed as separate subsystems, although they may have, in certain circumstances, a significant impact on final solution [2].

\subsection{Structure of the subsystem destruction of rock mass}

In this model, the followings occur as the input parameters:

f - coefficient of strength,

B - drilling of rocks,

$\mathrm{g}$ - resistence to destruction,

D - degree of cracking,

$\mathrm{S}$ - cross-section surface of the room, and

M - annual volume of works expressed in meters of constructed rooms.

As the output - desired parameters, the followings are adopted:

$1 \cdot \eta$ - progression of room for one cycle,

$\mathrm{Q}$ - volume of blasted rock materials,

$\mathrm{T}$ - time of drilling, and

C - costs of drilling.

As the parameters that depend on technical and organizational conditions:

$\mathrm{v}$ - drilling rate and drilling and mining parameters of works:

q - specific consumption of explosives,

1 - depth of bore holes,

$\mathrm{N}$ - number of bore holes,

$\mathrm{d}$ - diameter of bore holes,

$A_{\text {ex }}$ - energy characteristics,

D - construction of mine, method of initiation and ignition,

Qorg - organization.

As variable and random sizes:

$\mathrm{B}$ - drilling of rocks,

$\mathrm{O}_{\mathrm{t}}$ - interruption in work,

$\mathrm{O}_{\mathrm{e}}$ - discontinuation due to a lack of energy, and

$\mathrm{D}_{\mathrm{dr}}$ - other factors from this group. 
Model of this subsystem is shown in Figure 3.

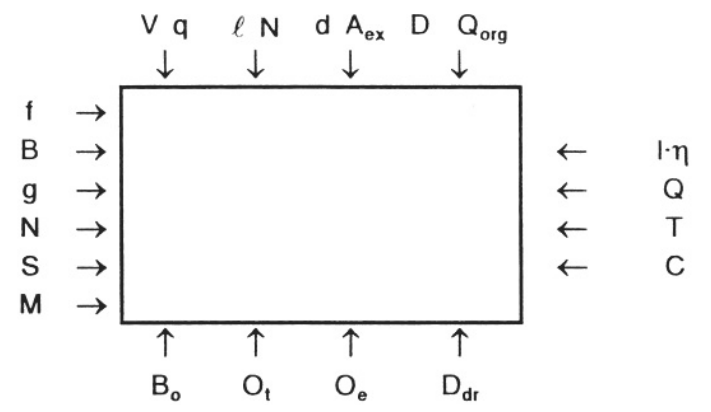

Figure 3 Model structure of subsystem destruction of the rock mass

Of all possible solutions and parameters, it is necessary to determine those solutions and those parameters that will provide the desired conditions with the least possible costs [3].

\subsection{Structure of the subsystem ventilation}

The input parameters are:

$\mathrm{S}$ - cross-section surface of room,

$\mathrm{L}$ - designed length,

$\mathrm{H}$ - depth of room,

$\mathrm{Q}_{\mathrm{ex}}$ - consumption of explosive per cycle,

$\mathrm{n}_{\text {rad }}$ - number of emplyees at the worksite,

On the output side of the model, the desired parameters are:

$\mathrm{h}$ - required depression,
$\mathrm{Q}_{\text {vaz }}$ - the amount of air that should provide ventilation of facilities in time $\left(\mathrm{t}_{\mathrm{pr}}\right)$ with economically justified costs $\left(\mathrm{C}_{\text {prov }}\right)$.

The organizational significant parameters are:

I - organization and ventilation scheme,

$\mathrm{N}$ - number of fans,

$\mathrm{K}$ - optimality of ventilation parameters and others.

The used random variables are:

$\mathrm{P}_{\text {vent }}$ - disruptions in fan operation,

$\mathrm{P}_{\mathrm{en}}$ - lack of energy, and

D - other reasons.

From all these parameters, those should be chosen that will provide the required conditions and a stable system of ventilation. The model of this subsystem is shown in Figure 4.

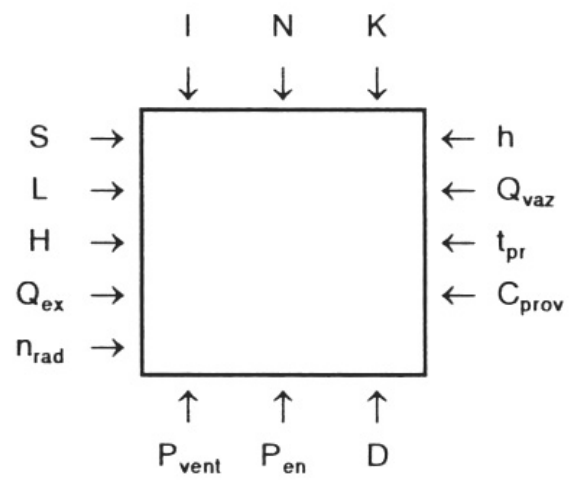

Figure 4 Structure of the subsystem ventilation model 


\subsection{Structure of the subsystem of loading and transport of blasted material}

The main input parameters of this model are

$\mathrm{S}$ - cross-section surface of facilities,

$\mathrm{L}$ - room length,

$\mathrm{Q}$ - volume of blasted material, and

M - annual volume of works on preparation.

The distinguished output parameters are:

$\mathrm{t}$ - length of loading, and

$\mathrm{C}_{\mathrm{tr}}$ - costs of transport and loading.

The important organizational parameters are:

E - way of loading and type of loading machine,

F - way of wagon changing,

$\mathrm{P}_{\mathrm{ut}}$ - capacity of loader,
$\mathrm{O}_{\mathrm{tr}}$ - organization of transport and other parameters.

The important random parameters are:

$\mathrm{G}$ - increase of non-dimensional pieces,

$\mathrm{Q}_{\mathrm{tm}}$ - failure of loader,

$\mathrm{P}_{\mathrm{e}}$ - interruption in power supply, and

$\mathrm{D}$ - other reasons.

Optimum in this model for required conditions is achieved for the case when the loader operation is the shortest and costs are the lowest. Thus, the solution of this task (model) is led to the achievement of maximum loading capacity (Put $\rightarrow$ max), while the loading time is as short as possible (tut $\rightarrow$ min). The model of this subsystem is shown in Figure 5.

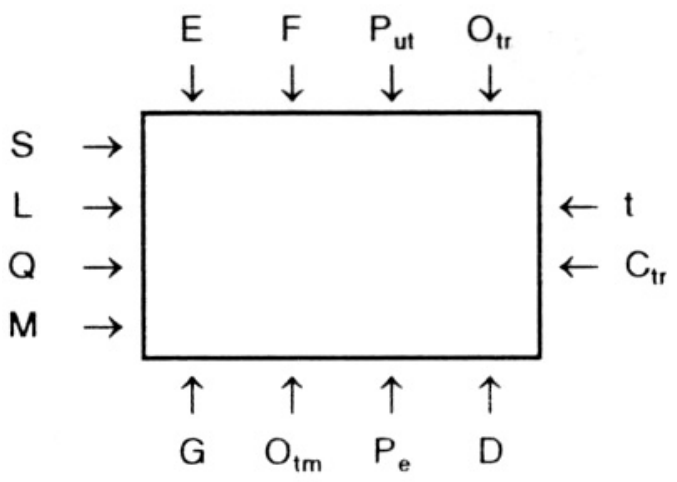

Figure 5 Structure of subsystem loading and transport of blasted material

\subsection{Structure of the supporting subsystems}

The main input parameters are: $\mathrm{S}$ - cross-section surface of facilities, $\mathrm{H}$ - depth of room,

$\mathrm{T}$-period (time) of room usage, $\mathrm{f}-$ coefficient of rock strength.

The important desired (output) data are:

$\mathrm{t}_{\text {pod }}$ - lifetime of support,

$\mathrm{C}_{\text {pod }}$ - cost of support, and

$\mathrm{F}_{\text {pod }}$ - functionality of support.
Characteristic organizational parameters are:

$\mathrm{K}_{\text {pod }}$ - applied economics of supporting construction,

$\mathrm{O}_{\text {pod }}$ - designed parameter (volume) of supporting construction,

$\mathrm{P}_{\text {pod }}$ - securing the necessary capacity of support,

$\mathrm{O}_{\text {org }}$ - organization in support construction works. 

The random variable parameters are:
$\mathrm{f}_{0}$ - frequent and significant change the coefficient of rock mass strength,

$\mathrm{X}_{\text {pod }}$ - support damage, and

$\mathrm{D}_{\text {pod }}$ - other factors.

Model of this subsystem is shown in Figure. 6.

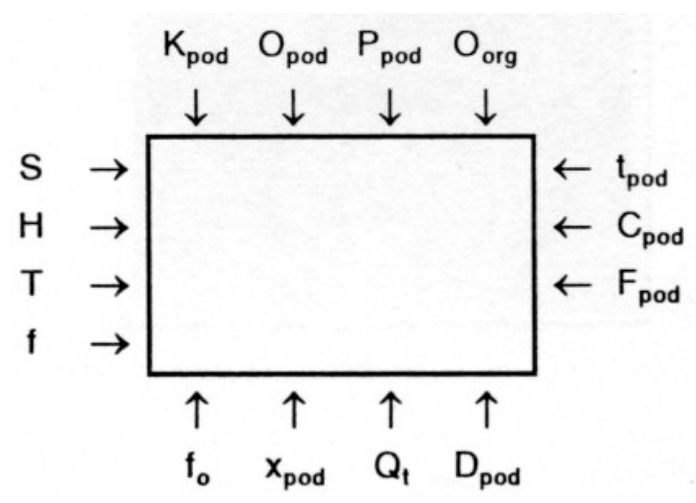

Figure 6 Model structure of supporting subsystem

\section{CONCLUSION}

Based on a detailed study of geomechanical conditions, technological processes and organization of work, it is possible to reach from the standpoint of development the underground mine facilities, necessary data from which it is possible to design a new technology, organization of work, to carry out necessary industrial tests and checking, based on the obtained data - using the corresponding mathematical models, to define an optimal technology and work organization.

Based on the results obtained in natural conditions (optimal pits and different working environments) and their detailed analysis by the accepted mathematical methods and modern programs, the possibilities were created for comprehensive processing of problems by number and variety of data and obtaining the results that are verifiable in practice.

Based on all these processed elements, the possibilities were created for designing an optimal processing technology and work organization in which the problem of development rate and costs of construction are conditioned by techno-economic possibilities and requirements of this economic branch.

\section{REFERENCES}

[1] B. Nedeljković, Studying the Impact of Technical-Economic Indicators Using the Method of Contour Blasting in Development the Underground Facilities in Hard Work Environment, Phd Thesis, Belgrade, 1996, pp. 1-212, RGF Belgrade;

[2] P. Jovanović, Development of the Underground Mine Facilities, Book I, Belgrade, 1973, RGF;

[3] D. Radulović, Numerical Methods, Belgrade, 1991. 


\begin{tabular}{ll}
\hline \hline INSTITUT ZA RUDARSTVO I METALURGIJU BOR & ISSN: 2334-8836 (Štampano izdanje) \\
UDK: 622 & ISSN: 2406-1395 (Online) \\
\hline \hline
\end{tabular}

\section{TEORETSKE POSTAVKE PRI IZRADI PODZEMNIH PROSTORIJA U RAZLIČITIM GEOMEHANIČKIM USLOVIMA***}

\section{Izvod}

Cilj ovog rada je postizanje racionalne brzine izrade prostorije uz najniže troškove izgradnje $i$ maksimalno mogući kvalitet (pod kvalitetom u ovom slučaju se podrazumeva zadovoljavajuća stabilnost konture izrađene prostorije $i$ iskopni profil što bliži obliku i veličini projektovanog).

Primenjene metode istraživanja su analiza izrade podzemnih prostorija kao složenog sisitema sa znatnim brojem maksimalno zavisnimh elemenata koji su unutar ovog složenog sistema uslovljeni radnom sredinom, organizacijom, mehanizacijom, energijom i drugim činiocima za ostvarivanje ovog cilja.

Rezultati ovih istraživanja ukazuju da je proces izrade podzemnih prostorija funkcionalno vezan i da zavisi od čitavog niza međusobno povezanih činilaca. Kao rezultat dobijamo da sa odgovarajućim matematičkim modelima može se definisati optimalna tehnologija i organizacija rada na izradi podzemnih prostorija.

Ključne reči: geomehanički uslovi, tehnologija izrade, porzemne prostorije, sistemi, zavisni elementi, matematički modeli

\section{UVOD}

lzrada podzemnih prostorija, bez obzira o kojoj se vrsti prostorija radi, (hodnici, uskopi, niskopi, okna, komore, tuneli i prostorije druge namene), predstavlja veoma složen sistem sa znatnim brojem međusobno zavisnih elemenata, koji su unutar ovog složenog sistema uslovljeni: radnim uslovima, organizacijom, mehanizacijom. energijom i drugim činiocima od značaja za ostvarenje opšteg cilja, postizanje racionalne brzine izrade prostorije, uz najniže troškove izgradnje i maksimalno mogući kvalitet (pod kvalitetom u ovom slučaju se podrazumeva zadovoljavajuća stabilnost konture izrađene prostorije $i$ iskopni profil što bliži obliku i veličini projektovanog).

Ovim i ovako veoma oštrim zahtevima, u uslovima kakva je promenljiva i često nepoznata stenska masa, ponekad je teško udovoljiti, za šta postoje mnogi razlozi: nedovoljno poklanjanje pažnje procesu izrade podzemnih prostorija, nedovoljno poznavanje uslova pod kojima će biti rađena prostorija, neodgovarajući tehnološki postupak izrade, loša organizacija rada, neusklađenost opreme sa radnim uslovima, neobučenost radnika i mnogi drugi činioci. Do objektivne procene, da li su svi postavljeni

\footnotetext{
*Univerzitet u Prištini sa privremenim sedištem u Kosovskoj Mitrovici, Fakultet tehničkih nauka, Kneza Miloša 7, Kosovska Mitrovica, e-mail: blagojenedeljkovic@yahoo.com

** Izvedeno istraživanje je podržano od strane Ministarstva prosvete, nauke i tehnološkog razvoja Republike Srbije (Projekat br. III43007, Projekat br. TR.33045)
} 
uslovi zadovoljeni (optimalna brzina izrade, najniži mogući troškovi izrade i kvalitet izrađene prostorije), moguće je doći samo posle detaljne analize zasnovane na velikom broju informacija, do kojih se dolazi snimanjem u realnim radnim uslovima svih elemenata $\mathrm{u}$ tehnološkom sistemu izrade prostorije. Tek na osnovu analize prikupljenih podataka moguće je proceniti uspešnost primenjene tehnologije, opreme, organizacije $\mathrm{i}$ drugih elemenata koji ulaze $\mathrm{u}$ sastav jednog ovakvog sistema, izvršiti potrebne dopune i izmene i približiti se postavljenim zahtevima u vezi racionalnosti i kvaliteta.

Sva složenost, vezana za izradu podzemnih prostorija, ogleda se kroz nezavisnost delovanja i ponašanja pojedinih elemenata podsistema koji ulaze u sastav tehnologije izrade, kao i velika promenljivost (u vremenu i prostoru) radnih uslova i sa ovim promenama uslovljavanje i izmene tehnološkog rešenja, ili pojedinih elemenata i delova ovih podsistema. Isto tako, i stalna promena položaja radnog mesta (čela), sredstava za rad i radne snage, razlog su izmenama uslova rada i efikasnosti samog procesa.

Kao posledica stalnih promena uslova rada, mesta rada i efikasnosti sredstava za rad, smanjuje se značaj i pouzdanost prikupljenih informacija na jednom mestu za donošenje odluka za rad na nekom drugom mestu, što otežava, kod čestih promena radnih uslova, definisanje jednog jedinstvenog tehnološkog rešenja izrade i transporta. Pitanje definisanja neke jedinstvene tehnologije u ovakvim uslovima je izuzetno složeno. Proces izrade postaje još složeniji, ako se izrada posmatranog objekta ne može posmatrati izolovano od sistema koji ga okružuje i sa kojim je on u funkcionalnoj povezanesti. Kao primer, može se istaći da, proces uklanjanja izminiranog materijala na čelu radilišta ne može biti nezavistan od sistema transporta i izvoza u okviru jame, proces bušenja nije moguć ukoliko nije usaglašen sa mogućnošću snabdevanja sredstava za bušenje pogonskom energijom itd. Svi ovi primeri ukazuju da je proces izrade podzemne prostorije funkcionalno vezan sa okruženjem, i da zavisi od čitavog niza međusobno povezanih činilaca, koji se mogu, za ove potrebe, izdvojiti kao:

- radna sredina,

- organizaciona povezanost sa ostalim tehnološkim procesima u sistemu jame,

- tehnološka šema jame,

- tehnološka opremljenost procesa i

- značaj podzemnog objekta za tehnološki proces jame kao celine.

Svi ovi činioci direktno utiču na efikasnost tehnološkog procesa izrade podzemne prostorije, i posebno se moraju izučavati. S obzirom na složenost procesa izrade podzemnih prostorija, i na to da je promenljivost činilaca koji utiču na proces izrade ponekad značajna, to je za donošenje ocene o procesu izrade ili nekog od elementa izrade, neophodno jako mnogo informacija. Obično se ove informacije dobijaju direktnim snimanjem radnih procesa $\mathrm{i}$ njihovih elemenata $\mathrm{i}$ statističkom obradom dobijenih podataka. Nakon toga se utvrđuje stepen njihove pouzdanosti i pronalaženje, pomoću matematičkih metoda, određenih veza i prirode njihove međuzavisnosti. Matematičkim jezikom rečeno, ove veze obično se iskazuju u obliku neke zavisnosti za traženu pojavu, od jednog ili više uticajnih činilaca:

$$
\mathrm{F}=\mathrm{f}(\mathrm{a}, \mathrm{b}, \mathrm{c}, \ldots) \text {. }
$$

Analiza tehnologije izrade podzemnih prostorija može biti izvršena na više različitih načina, od kojih je sistem kompleksnog izučavanja problematike izrade i utvrđivanja značaja uticajnih činilaca u tehnološkom procesu za sada našao najviše pristalica. Ovaj sistem omogućava da se tehnološki proces izrade razdvoji na više podsistema (radnih operacija), a podsistemi na sastavne elemente i zahvate, koji potpuno nezavisno jedan od drugog, a i kao celina, korišćenjem logičkog, matematičkog i organizacionog modeliranja omogućava, da se sa 
različitih aspekata da potrebna ocena brzine napredovanja - efikasnosti, stepena iskorišćenja raspoloživog vremena, iskorišćenja raspoloživih kapaciteta, opreme i radne snage, normativa, cene izrade, kvaliteta izrade i dr. Sistem kompleksnog izučavanja tehnologije izrade, ili elemenata i podsistema primenjenog ili projektovanog tehnološkog procesa, može veoma dobro da posluži prilikom organizovanja ili analize već primenjenog tehnološkog procesa.

\section{METODOLOŠKI PRISTUP PRIMENI KOMPLEKSNOG IZUČAVANJA$$
\text { TEHNOLOGIJE IZRADE }
$$$$
\text { PODZEMNE PROSTORIJE }
$$

Sistem kompleksnog izučavanja tehnologije izrade podzemne prostorije, ili pojedinih delova tehnološkog procesa, omogućava objektivnije sagledavanje svih činilaca koji aktivno deluju u okviru zahvata, radnih procesa ili radnog ciklusa projektovane ili primenjene tehnologije izrade. Zahvaljujući ovakvom sagledavanju činilaca i njihovih međuzavisnosti, moguće je kod postojećih tehnoloških procesa izvršiti odgovarajuće inovacije i izmene, a kod novoprojektovanih, već u samom startu, organizaciono i tehnološki uskladiti međuodnose, sve sa ciljem da tehnološki proces besprekorno organizaciono i tehnološki funkcioniše, u funkciji postizanja maksimalne efikasnosti i uz najmanja ulaganja.

Prilikom analize jednog ovakvog sistema neophodno je prvo rasčlaniti uticajne činioce prema njihovoj prirodi na:

- ulazne,

- željene,

- organizacione i

- slučajne - nekontrolisane parametre.

Šematski prikaz ovakvog modela dat je na slici 1. Sa (A) su označeni parametri vezani za: rudarsko - geološke uslove, teh- nološke karakteristike stenske mase, oprema i sl. Sa (B) su označeni željeni rezultati: brzina izrade prostorije, učinak, cena izrade i sl. Sa (C) su označeni parametri organizaciono - tehničke prirode: režim rada, organizacija, stepen mehanizovanosti radnih operacija, parametri bušenja i miniranja (za slučaj kada je korišćena metoda miniranja za razaranje stenske mase), materijal i sl. Sa (D) su označeni slučajni ili primenjivani parametri tehnološkog procesa i stabilnosnih karakteristika stenske mase, nepredviđeni prekidi u radu vezani za: nedostatak energije, pomoćnog materijala, razni zastoji i dr. Ovde treba imati u vidu da željeni rezultat (B), pored osnovnog uticaja (A), u najvećoj meri zavisi i od uslova i parametara datih pod (C), mada ni uticaj činilaca (D) ne sme biti zanemaren, jer ponekad ovi uticaji mogu imati značajan uticaj na formiranje konačnog rešenja i postizanje krajnjih efekata. Znajući sve ove činjenice, nužno je prihvatiti da na zbivanja koja se dešavaju unutar jednog ovakvog modela, značajan udeo imaju sva tri činioca, tako da konačan rezultat predstavlja njihovu zajedničku sintezu, što dozvoljava da se matematički izraz tražene vrednosti iskaže u obliku:

$$
\text { B }=\text { f (A. C. D). }
$$

Nesumljivo da jedan ovakav model može biti zavistan od velikog broja činilaca, koji, svaki pojedinačno po svom uticaju na konačan rezultat, mogu imati različite težine. Iz ovog razloga, a u cilju racionalizacije i efikasnijeg rešavanja problema, potrebno je izdvojiti samo one činioce koji imaju značajniji uticaj na ponašanje modela. Ovako definisan model omogućava da se, prema želji i potrebama, nađu najpovoljnija rešenja (minimum ili maksimum vrednosti), već prema karakteru same pojave i traženog podatka. Na slici 2. prikazana je šema modela tehnološkog sistema u oblasti izrade podzemnih prostorija. 


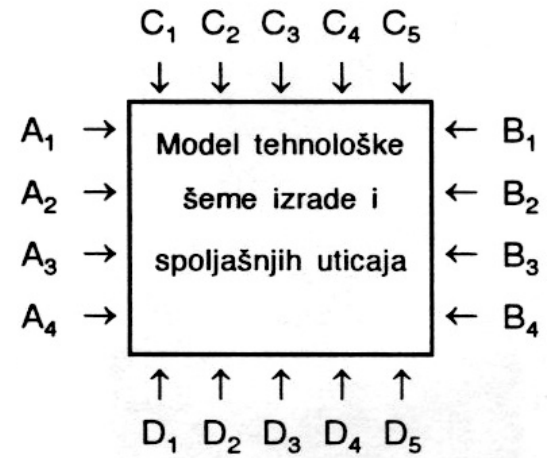

Sl. 1. Šema modela tehnološkog sistema u oblasti izrade podzemnih prostorija

Tehnološki proces izrade podzemnih prostorija (bez obzira na tehnološka rešenja), prema dinamičkom planu izrade, predstavlja ciklično rešenje, kod koga su u svakom ciklusu, sastavni elementi ciklusa tesno međusobno povezani i odvijaju se po napred utvrđenom redosledu, što omogućava da se ovakav sistem posmatra kao stabilan sistem sastavljen od više podsistema, koji slede jedan za drugim. Na slici 2. prikazana je jedna tehnološka šema izrade, posmatrana kao sistem sastavljen od većeg broja nezavisnih podsistema.
Ovako postavljen problem svodi se na postupak pronalaženja takvih varijantnih rešenja, koja će u datim uslovima obezbediti i najpovoljnije rezultate, ne samo svakog pojedinačnog podsistema, već i sistema kao celine. Kod rešavanja ovakvih problema neophodno je izvršiti analizu sa sledećih aspekata: tehnološkog (stvarne mogoćnosti primene analiziranog rešenja), organizacionog (mogućnost organizacionog sprovođenja analiziranog rešenja) i potrebnog vremena za izvršenje predviđenog posla (izbor varijanti koje su najpovoljnije sa stanovišta vremenskog uklapanja u ciklus i organizacione šeme jame).

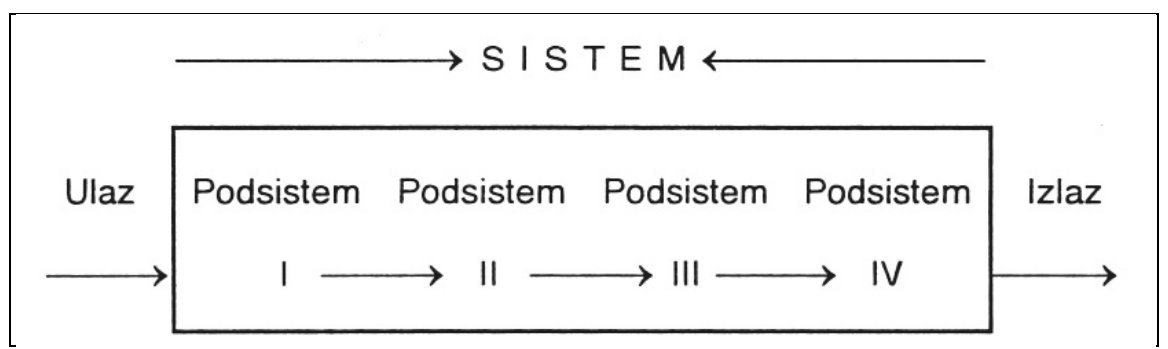

Sl. 2. Šematski prikaz tehnologlje izrade podzemne prostorije u obliku nezavisnog sistema sastavljenog od više podsistema koji su međusobno tesno povezani: I - Podsistem razaranja stenske mase; II - Podsistem provetravanja radilišta; III - Podsistem utovara i transporta izminiranog stenskog materijala; IV - Podsistem podgrađivanja prostorije

Pronalaženje kriterijuma, na osnovu kojeg će biti utvrđivana optimalnost podsistema i sistema, s obzirom na veliki broj alternativnih rešenja, predstavlja složeno pitanje. Zato se kod ovakvih istraživanja pokazalo znatno zahvalnijim pronalaženje 
uslova pod kojim se postiže najveći učinak (u ovom slučaju najveće napredovanje), uz najmanje materijalne izdatke (u ovom slučaju najniža cena izrade). U matematičkoj teoriji, ovaj postupak poznat je kao teorija uzajamnosti. Ovakav kriterijum obično se obrazuje kao zbir proizvoda kriterijuma pojedinačnih pojava $(\mathrm{k})$, sa nekim koeficijentom (f), koji definiše značaj svake od posmatranih pojava:

$$
\mathrm{U}=\mathrm{f}_{1} \cdot \mathrm{k}_{1}+\mathrm{f}_{2} \cdot \mathrm{k}_{2}+\mathrm{f}_{\mathrm{n}} \cdot \mathrm{k}_{\mathrm{n}} \rightarrow \max (\min )
$$

Prilikom analize tehnološkog postupka izrade podzemne prostorije, za slučaj različitih varijantnih rešenja, najčešće se problem razmatra sa stanovišta postizanja najveće brzine izrade (v) uz najmanje troškove izrade (c). Ovaj kriterijum dat u obliku linearne veze, glasi:

$$
\mathrm{U}=\mathrm{f} \cdot\left(\mathrm{f}_{1} \cdot \mathrm{c}+\mathrm{f}_{2} \cdot \mathrm{v}\right),
$$

gde su: $\mathrm{f}_{1}<0 \mathrm{i} \mathrm{f}_{2}>0$ - koeficijenti težine, koji uzimaju u obzir značaj pokazatelja troškova i brzine izrade.

Kod rešavanja praktičnih slučajeva i zadataka ne teži se dobijanju idealne vrednosti odabranog kriterijuma, s obzirom da rezultati, koji su dobijeni terenskim opažanjima nisu u potpunosti adekvatni zamišljenom modelu.

\section{STRUKTURA SISTEMA I PODSISTEMA ODABRANOG MODELA IZRADE}

Kao metoda izrade pozemnih prostorija, u ovom slučaju, usvojen je sistem sa razaranjem stenske mase na čeIu prostorije uz pomoć miniranja. Ovakav sistem sastoji se od više podsistema, među kojima se kao osnovni izdvajaju sledeći:

- podsistem razaranja stenske rnase (I),

- podsistem provetravanja (II),

- podsistem utovara i transporta miniranog stenskog materijala (Ill), i

- podsistem podgradivanja (IV).

Ostali podsistemi: dolazak i odlazak na i sa radilišta, priprema radilišta, doprema materijala i pomoćni radovi (izrada kanala za vodu, produženje koloseka, produženje cevi za sabijeni vazduh, cevi za vodu i cevi za separatno provetravanje), uvršćeni su $\mathrm{u}$ organizacione i režijske poslove, i iz tog razloga neće biti analizirani kao posebni podsistemi, iako oni mogu imati u određenim uslovima značajan uticaj na konačno rešenje [2].

\subsection{Struktura podsistema razaranja stenske mase}

Kod ovog modela kao ulazni parametri javljaju se:

f - koeficijent čvrstoće,

B - bušivost stene,

g - otpor prema razaranju,

D - stepen ispucalosti,

S - površina poprečnog preseka prostorije $\mathrm{i}$

M - godišnji obim radova izražen u metrima izrađenih prostorija.

Kao izlazni - željeni parametri usvojeni su:

$1 \cdot \eta$ - napredovanje prostorije za jedan ciklus,

Q - zapremina miniranog stenskog materijala,

$\mathrm{T}$ - vreme bušenja i

C - troškovi bušenja.

Kao parametri koji zavise od tehničkoorganizacionih uslova:

$\mathrm{v}$ - brzina bušenja i parametri bušačko-minerskih radova:

q - specifična potrošnja eksploziva,

1 - dubina bušotina,

$\mathrm{N}$ - broj bušotina,

d - prečnik bušotine,

$\mathrm{A}_{\mathrm{ex}}$ - energetske karakteristike,

D - konstrukcija mine, način iniciranja i paljenja,

$\mathrm{Q}_{\text {org }}$ - organizacija.

Kao promenljive i slučajne veličine:

$\mathrm{B}$ - bušivost stene,

$\mathrm{O}_{\mathrm{t}}$ - prekid $\mathrm{u}$ radu,

$\mathrm{O}_{\mathrm{e}}$ - prekid zbog nedostatka energije i

$\mathrm{D}_{\mathrm{dr}}$ - drugi činioci iz ove grupe. 
Model ovog podsistema prikazan je na slici 3.

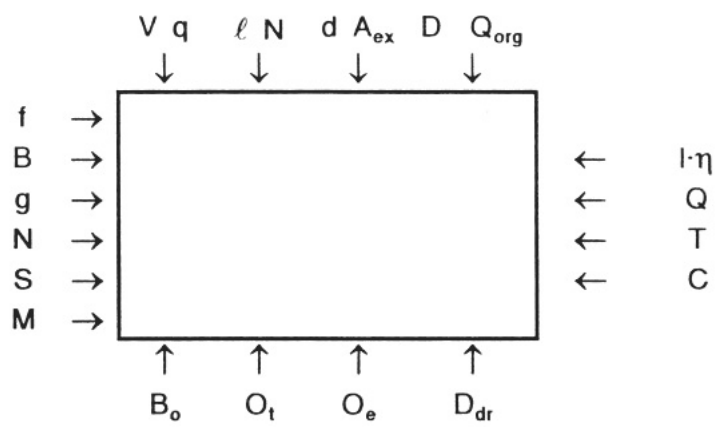

Sl. 3. Struktura modela podsistema razaranja stenske mase

Od svih mogućih varijantnih rešenja i parametara treba utvrditi ona rešenja $i$ one parametre koji će obezbediti željene uslove uz najmanje moguće troškove [3].

\subsection{Struktura podsistema provetravanja}

Kao ulazni parametri definisani su:

$\mathrm{S}$ - površina poprečnog preseka prostorije,

L - projektovana dužina,

$\mathrm{H}$ - dubina prostorije,

$\mathrm{Q}_{\mathrm{ex}}$ - utrošak eksploziva po ciklusu, $\mathrm{n}_{\text {rad }}$ - broj zaposlenih na radilištu,

Na izlaznoj strani modela željeni parametri su:

$\mathrm{h}$ - potrebna depresija,
$\mathrm{Q}_{\mathrm{vaz}}$ - količina vazduha koja treba da obezbedi provetravanje prostorije za vreme $\left(\mathrm{t}_{\mathrm{pr}}\right)$ uz ekonomski opravdane troškove $\left(\mathrm{C}_{\text {prov }}\right)$.

Od organizacionih parametara značajni su:

I - organizacija i šema provetravanja, $\mathrm{N}$ - broj ventilatora,

$\mathrm{K}$ - optimalnost parametara provetravanja $\mathrm{i}$ dr.

Kao slučajne promenjive korišćene su:

$\mathrm{P}_{\text {vent }}$ - prekidi u radu ventilatora,

$\mathrm{P}_{\mathrm{en}}$ - nedostatak energije, $\mathrm{i}$

D - drugi razlozi.

Od svih ovih parametara treba odabrati one koji će obezbediti tražene uslove i stabilan sistem provetravanja. Model ovog podsistema prikazan je na slici 4.

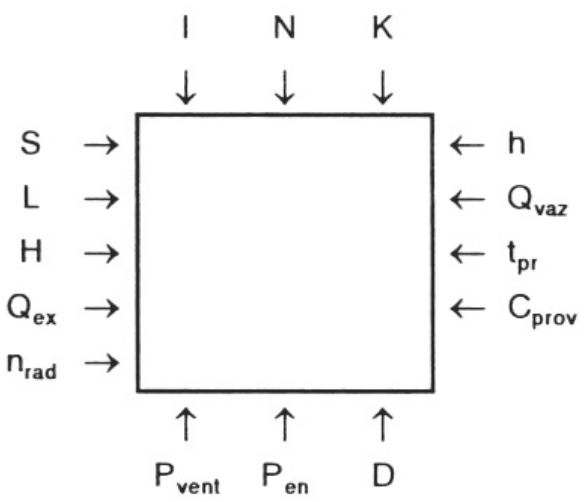

SI. 4. Struktura modela podsistema provetravanja 


\subsection{Struktura podsistema utovara $i$ transporta izminiranog materijala}

Osnovni ulazni parametri kod ovog modela su:

S - površina poprečnog preseka prostorije,

$\mathrm{L}$ - dužina prostorije,

Q - zapremina miniranog materijala i

M - godišnji obim radova na izradi.

Kao izlazni parametri izdvajaju se:

$\mathrm{t}$ - dužina utovara $\mathrm{i}$

$\mathrm{C}_{\mathrm{tr}}$ - troškovi transporta i utovara.

Od organizacionoh parametara značajni su:

E - način utovara i tip mašine za utovar,

$\mathrm{F}$ - način izmene vagoneta,

$\mathrm{P}_{\mathrm{ut}}$ - kapacitet utovarača,
$\mathrm{O}_{\mathrm{tr}}$ - organizacija transporta $\mathrm{i}$ drugi parametri.

Od slučajnih parametara značajni su:

$\mathrm{G}$ - povećanje negabaritnih komada,

$\mathrm{Q}_{\mathrm{tm}}$ - otkaz mašine za utovar,

$\mathrm{P}_{\mathrm{e}}$ - prekid $\mathrm{u}$ dovodu energije $\mathrm{i}$

D - drugi razlozi.

Za tražene uslove optimum se kod ovog modela postiže za slučaj kada je operacija utovara najkraća, a troškovi najniži. Prema tome, rešenje ovog zadatka (modela) svodi se na postizanje najvećeg mogućeg kapaciteta utovara ( $\left.\mathrm{P}_{\mathrm{ut}} \rightarrow \max \right)$, a da pri tome vreme utovara bude što kraće $\left(t_{u t} \rightarrow \min \right)$. Model ovog podsistema prikazan je na slici 5.

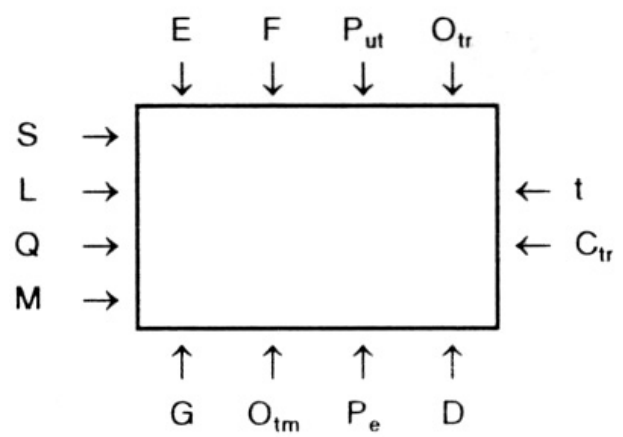

Sl. 5. Struktura modela podsistema utovara i transporta izminiranog materijala

\subsection{Struktura podsistema podgrađivanja}

Osnovni ulazni parametri su:

$\mathrm{S}$ - površina poprečnog preseka prostorije,

$\mathrm{H}$ - dubina prostorije,

$\mathrm{T}$ - period (vreme) korišćenja prostorije,

f - koeficijent čvrstoće stene.

Od željenih (izlaznih) podataka bitni su: $\mathrm{t}_{\text {pod }}$ - vek trajanja podgrade,

$\mathrm{C}_{\text {pod }}$ - cena koštanja podgrade $\mathrm{i}$

$\mathrm{F}_{\text {pod }}$ - funkcionalnost podgrade.
Od organizacionih parametara mogu se izdvojiti:

$\mathrm{K}_{\text {pod }}$ - ekonomičnost primenjene konstrukcije podgrade,

$\mathrm{O}_{\text {pod }}$ - projektovani parametar (obim) podgrade konstrukcije,

$\mathrm{P}_{\text {pod }}$ - obezbeđenje potrebne nosivosti podgrade,

$\mathrm{O}_{\text {org }}$ - organizacija pri izvođenju radova na podgrađivanju. 
Od slučajnih promenljivih parametara prisutni su:

$f_{0}$ - česta i značajna promena koeficijenta čvrstoće stenske mase,
$\mathrm{X}_{\text {pod }}$ - oštećenje podgrade $\mathrm{i}$

$\mathrm{D}_{\text {pod }}$ - drugi činioci.

Model ovog podsistema prikazan je na slici 6.

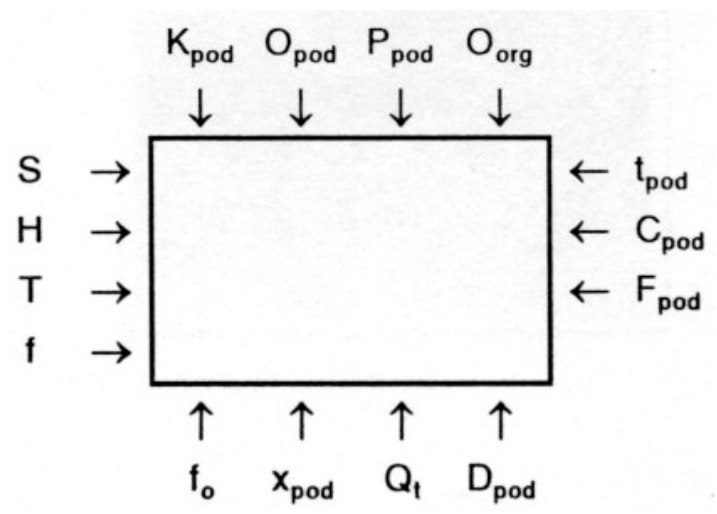

Sl. 6. Struktura modela podsistema podgrađivanja

\section{ZAKLJUČAK}

$\mathrm{Na}$ osnovu detaljnog izučavanja geomehaničkih uslova, tehnoloških procesa $\mathrm{i}$ organizacije rada moguće je doći do - sa stanovišta izrade jamskih prostorija, neophodnih podataka na osnovu kojih je moguće projektovanje nove tehnologije, organizacije rada, izvršiti potrebna industrijska ispitivanja i provera na osnovu ovako dobijenih podataka - koristeći se odgovarajućim matematičkim modelima, definistai optimalnu tehnologiju i organizaciju rada.

$\mathrm{Na}$ osnovu rezultata koji se dobijaju u prirodnim uslovima (optimalnim jamama i razlićitim radnim sredinama) i njihovom detaljnom analizom uz pomoć prihvaćenih matematičkih metoda i savremenih programa stvorene su mogućnosti da se ovako po broju i raznovrsnosti podataka složena problematika sveobuhvatno obradi i dobiju rezultati koji su u praksi proverljivi.
Na osnovu svih ovako obrađenih elemenata stvorene su mogućnosti za projektovanje optimalne tehnologije izrade i organizacije rada kod koje je problem brzine izrade i cene izrade uslovljena sa tehnoekonomskim mogućnostima i zahtevima ove privredne grane.

\section{LITERATURA}

[1] B. Nedeljkjović, Proučavanje uticaja tehničko - ekonomskih pokazatelja primenom metode konturnog miniranja pri izradi jamskih objekata u čvrstoj radnoj sredini, doktorska disertacija, Beograd, 1996, str 1-212, RGF.

[2] P. Jovanović, Izrada jamskih prostorija, Knjga I, Beograd, 1973, RGF.

[3] D. Radulović, Numeričke metode, Beograd, 1991. 